\title{
Post-legislative Scrutiny in the Process of Democratic Transition in Malaysia
}

\author{
Khoo Ying Hooi \\ University of Malaya \\ Email: yinghooi@um.edu.my
}

\begin{abstract}
Malaysia's 14 $4^{\text {th }}$ general election in 2018 saw the fall of the Barisan Nasional (BN) regime after ruling the country for more than six decades. Prior to the election, Malaysia faced challenges ranging from the absence of state legitimacy, fragile institutions to corruption scandals, leaving little room to have robust discourse on legislative reforms. Promise 16 of the Pakatan Harapan (PH) election manifesto prior to the election, pledges to restore the dignity of Parliament to institutionalize the select committee system in Parliament and the Senate to enable them to function effectively. Whilst there is limited post-legislative scrutiny (PLS) in Malaysia for now, the various reforms in the phase of democratic transition to the administration of $\mathrm{PH}$ is a positive sign of the possibility for Malaysia to move into better lawmaking procedures. This paper examines the work that is currently being undertaken in the Parliament of Malaysia to assess whether the current parliamentary reforms can pave the way for the PLS mechanism to be put in place.
\end{abstract}

Keywords: Malaysia, Democratic Transition, Parliamentary Reforms, Post-legislative Scrutiny, Pakatan Harapan

\section{INTRODUCTION}

For decades, democracy in Malaysia has been considered a "flawed democracy" in which civil liberties are not fully guaranteed. ${ }^{1}$ For democratic transition to take place in a diverse society like Malaysia, it is important to redefine the separation of powers among the three key branches of the structure, namely executive, judicial and legislative. This is to ensure the functionality of the check and balance system, whereby each branch is given certain powers to check and balance the other branches. Such practice should be respected in a democratic setting. A total of 12.2 million Malaysians casted their ballots in the $14^{\text {th }}$ general elections held on the 9th May 2018, in favour of candidates from the then-opposition coalition, the Pakatan Harapan (PH). This bought about the shocking defeat of Barisan Nasional (BN), this political coalition had ruled Malaysia since the country gained independence in 1957. Malaysians voted out the $\mathrm{BN}$ with the expectation that the new PH government will

1 Democracy Index 2017: Free speech under attack, by The Economist Intelligence Unit (2017). 
bring about positive changes. A total of sixty promises and five special commitments were made in PH's election manifesto. ${ }^{2}$ Some have been implemented; for instance the abolishment of the goods and services tax (GST). However, there are a significant number of these promises which entail institutional and legislative reforms and these require time to implement and instigate long-term impact. ${ }^{3}$

The PH won 112 out of a total of 222 parliamentary seats in 2018. They are led by the former Prime Minister Tun Dr. Mahathir Mohamad and this can be interpreted in a number of different ways. Malaysia's transition into a democracy underwent a combination the two transition processes, namely from above and below. Firstly, there was mounting pressures from the population culminating in the five mass protests staged by the electoral reform movement, Bersih since 2007. Secondly, there was the negotiation pact between the opposition and Tun Dr. Mahathir Mohamad, the then prime minister in the transformed PH coalition.

The change is a culmination of the Reformasi Movement in 1998 until the 2008 general elections termed the political tsunami. ${ }^{4}$ The $9^{\text {th }}$ of May opened up hope and opportunities for Malaysians to fix a flawed governance system and bring in substantive democracy that could bring in reforms for the people. Parliament is recognized as one of the starting points for the reform agenda to take place. ${ }^{5}$ One of the key parliamentary reforms is to strengthen the function of parliament by establishing more bi-partisan Special Select Committees, made up of parliamentary members that are appointed to deal with a particular issue or areas of issues. The mechanism of Special Select Committees originates from the Westminster system of parliamentary democracy, to ensure there are check and balance measures in place.

As provided by the Westminster Foundation of Democracy (WFD), the postlegislative scrutiny (PLS) is defined as the practice used to monitor and evaluate the implementation of legislation, ensuring laws benefit constituents in the way originally intended by lawmakers. This is based on the agreement that, as Parliament is responsible for adopting legislation, it then naturally has a role in monitoring the implementation of legislation and evaluating whether the laws it has passed have achieved their intended outcomes especially for the benefit of the public interest. It is commonly agreed that implementation can be a complicated process and it is often overlooked, therefore there is a need for Parliament to establish mechanisms in order to monitor the implementation of legislation and its efficaciousness.

Due to a lack of systematic study of PLS in the context of Malaysia, there is limited knowledge on how the process operates in practice especially in the process of democratic transition. Moreover, as a country with different ethnic and religious

2 Pakatan Harapan, "Buku Harapan: Rebuilding our nation, fulfilling our hopes”, (2018), online: <https://kempen.s3.amazonaws.com/manifesto/Manifesto_text/Manifesto_PH_EN.pdf〉.

3 Cassey Lee, "Making Sense of Malaysia’s Institutional Reforms" (2018) 79 ISEAS 11.

4 Khoo Ying Hooi, "A year after Malaysia changed government: A messy democracy but necessary”, The Malay Mail (8 May 2019), online: <https://www.malaymail.com/news/what-youthink/2019/05/08/a-year-after-malaysia-changed-government-a-messy-democracy-but-necessary$\mathrm{kh} / 1751027>$.

5 Maria Chin Abdullah, "Time for Parliamentary Reform”, (14 March 2019), online: The Sun Daily<https://www.thesundaily.my/opinion/time-for-parliamentary-reform-GM680923>. 
communities, the on-going democratic transition in Malaysia since the first regime change in 2018 after 61 years of independence offers a unique opportunity to examine whether the PLS could be implemented in such a context. This paper employs a qualitative method based on the author's own advocacy experiences within non-governmental organisations (NGOs). This approach allows the author to share their first-hand experience of the topic in view as well as the reforms under the new government of the PH administration which have taken place. Such approach enables the author to contribute to this paper as an insider and an advocate for this topic.

This paper seeks to analyse the potential mechanism of moving towards PLS built upon the framework of democratic transition in Malaysia. Firstly, it examines the present approach on parliamentary reforms and how these processes can be carried out by the Special Select Committees. Secondly, it examines to what extent the special Select Committees can have a real and practical impact on the new government's administration with a particular focus on institutional mechanisms currently available. The paper will also seek to identify their constraints and limitations in ensuring government accountability. The paper will begin by providing an overview of the process of democratic transition in Malaysia. The following section will investigate parliamentary and political reforms, particularly the roles and functions of Parliament and the Special Select Committees. It will then go on to assess the challenges for the Special Select Committees to engage in PLS work followed by the concluding remarks.

\section{THE MALAYSIAN POLITICAL CONTEXT AND DEMOCRATIC TRANSITION}

Understanding Malaysian parliamentary effectiveness requires an examination of its democratic trajectory and impact on broader society. After securing independence from the British in 1957, the subsequent Malaysian government was modelled on the Westminster system. It practises parliamentary democracy and is complemented by a constitutional monarchy with the Yang di-Pertuan Agong as the federal Head of State. ${ }^{6}$ Scholarship on the Malaysian political structures has classified the system as a "quasi democracy", "semi-democracy", and/or soft authoritarianism. ${ }^{9}$ These terms essentially characterize Malaysia as a hybrid, demonstrating democratic and authoritarian features. ${ }^{10}$

6 Ibid.

7 Zakaria Haji Ahmad, "Malaysia: Quasi Democracy in a Divided Society" in Larry Jay Diamond, Juan José Linz \& Martin Lipset, eds, Democracy in Developing Countries: Asia (L. Rienner, 1989).

8 William Case, "Malaysia: the semi-democratic paradigm” (1993) 17:1 Asian Studies Review 7582.

9 Gordon Paul Means, "Soft Authoritarianism in Malaysia and Singapore" (1996) 7:4 Journal of Democracy 103-117.

10 Mauzy Diane K, “The Challenge to Democracy Singapore’s and Malaysia's Resilient Hybrid Regimes" (2006) 2:2 Taiwan Journal of Democracy 47-68. 
The $\mathrm{BN}$ regime has largely dominated civil society during the course of its rule. The perpetuation of the $\mathrm{BN}$ regime and administration responded to the demands of its citizens, whilst manipulating them in a repressive manner so as to curb their fundamental rights resulting in a "responsive-repressive regime". ${ }^{11}$ The pluralitymajority electoral system, namely the first-past-the-post (FPTP) that grants parliamentary seats to those candidates who simply win most votes in their constituencies, is a legacy of British colonial rule. Understanding Malaysian politics today calls for an examination of the impact of its democratic trajectory on broader society.

Malaysia's $14^{\text {th }}$ General Election of 2018 marked a significant historical moment for the country. It was the first time the opposition coalition PH won the election and formed a new government. Prior to the downfall of the BN in GE14, 2008 and 2013, the general elections were regarded as two significant elections and both reflected the growing public discontent towards the BN. It was widely termed the 'political tsunami' ("Malaysia's elections: political tsunami," 10 March 2008). The victory officially ended the 61 years of BN domination. Since the winning of the PH under the leadership of Tun Dr. Mahathir Mohamad (his second time as the Prime Minister) the process of vigorous reform is being undertaken in institutional, legislative and parliamentary sectors; yet these are not without challenges. The new government now needs to live up to the high expectations of the public which has an enhanced awareness of the political situation in Malaysia. Moreover, there will be pressure to fulfil the promises the PH made in their election manifesto.

The issue of human rights in Malaysia has been the subject of on-going debate and is a heated topic involving various stakeholders such as policymakers, scholars, political activists and individuals. Progress in addressing human rights concerns in Malaysia is a product of decades of struggles for human dignity by Malaysians, individually and collectively. The rights of Malaysians to participate in civil society and protection of their basic civil liberties, are spelt out at length under the second part of the Federal Constitution, under the section on Fundamental Liberties. However, virtually all these freedoms are qualified by an overriding right of the government to decide otherwise if it wishes, whether it be in the interests of national security or public order. Prior to the election, fundamental rights of freedom of expression, peaceful assembly and association were strictly curtailed culminating in restrictions on opposition politicians and civil society groups.

The political system is strictly divided into partisan politics between the ruling party and the opposition party, the civil society groups are caught up in between hence face a lot of challenges. For instance, the political access to reform is extremely limited as there were few BN politicians who were friendly towards civil society actors. During the previous regime, civil society groups had little choice but to be more inclined toward the-then opposition party for support, help and to facilitate political access in order to push for advocacy and reforms within the system. The structure of the

11 Khoo Boo Teik, "Review of Goverment and Society in Malaysia" (1999) 72:2 (277) Journal of the Malaysian Branch of the Royal Asiatic Society 194-196. 
previous regime, perpetuated the idea that civil society groups are an enemy of the government but an ally of the opposition.

Government bureaucracy has also been criticised heavily for its inefficiency, corruption and failure to guard public interests which has led to growing public concern over poor performance of the bureaucracy and its lack of accountability and responsiveness. The new government under the PH coalition in their election manifesto promised to uphold democracy, rule of law and respect human rights. One immediate action by the new government was the formation of the 'Institutional Reforms Committee (IRC) comprising of five prominent figures to investigate institutional reforms in Malaysia.

In a democracy, it is widely recognized the government exercises checks and balances through its three branches: legislative, executive and judicial arms. For decades, the separation of powers has been a highly contentious issue hence the division of the three branches is often unclear. For instance in the past, the power of the executive increased to a certain level without the corresponding increase in parliament's ability to oversee these powers. This is one of the foremost challenges of the new government under the PH administration to find ways to help improve accountability in government and be answerable to the voters. During this transition period, a proper checks and balances mechanism is crucial to strengthen the legislature. One route is through the establishment of bi-partisan Special Select Committees. This will be discussed at length in the following sections. This paper attempts to answer whether the change in government will lead to a more democratic and open society. Will it lead to better access to the State and mechanisms to implement the PLS mechanism in an effective way? How do these democratic developments impact on the potential of having the PLS mechanism in place?

\section{PARLIAMENTARY REFORMS IN MALAYSIA}

In Malaysia, the House of Representatives has 222 elected members and each member represents a Parliamentary Constituency. A General Election is held every five years to elect members of the House of Representatives. Parties with the most elected members can form a federal government to rule the country. In Malaysia, the legal framework for Select Committees exists under the Parliament's Standing Orders (SOs). Currently, the SOs of the Dewan Rakyat provide for the establishment of five existing select committees: (1) the Committee of Selection (SO 76); (2) the Public Accounts Committee (SO 77); (3) the Standing Orders Committee (SO 78); (4) the House Committee (SO 79); and (5) the Committee of Privileges (SO 80). Unlike the Select Committees, Special Select Committees can be established when needed and for specific cases of special interest for the country. The Committees serve for a limited time period with specific terms of reference that govern the role and function of such Committees.

There are legal frameworks for setting up and outlines for the operations of Select Committees and Special Select Committees, in practice there has been limited use of these Committees to facilitate the Parliamentarians in undertaking their functions. The executive and the Attorney General's Chambers of the previous 
government were primarily responsible for the drafting of law. Although the SOs of the Dewan Rakyat or House of Representatives provided for the establishment of five Select Committees, as well as Special Select Committees, the Dewan Negara or Senate merely rubberstamped Bills to become law. For instance, while Parliament established the Public Accounts Committee, which has produced reports and engaged in debate sessions in Parliament, there have been no conclusions or sanctions for those responsible for financial losses. ${ }^{12}$ The quality of the discussions is often dependent on the extent civil servants are able or willing to respond to the queries raised by the Members of Parliament.

A total of sixty promises and five special commitments were made in PH's election manifesto ${ }^{13}$ prior to the $14^{\text {th }}$ General Elections. A significant number of these promises entail institutional, legislative and parliamentary reforms. In the $\mathrm{PH}$ election manifesto, the PH has pledged under Promise 16 to restore the dignity of Parliament recognizing it as an important institution to check executive powers and that it must have sufficient infrastructure and funding. In its manifesto, they mentioned should the PH government come to power, they would reintroduce the Parliamentary Services Act 1963, with improvements on certain matters to ensure the Act is applicable in the current environment. The manifesto also mentioned the Speaker of the Dewan Rakyat and the President of Dewan Negara would be members whose integrity and credibility are respected by their peers; they must retire from partisan politics as soon as they accept their posts. In addition, a Special Committee will be formed to receive and examine complaints from Members of Parliament to ensure that their decisions are fair. Promise 16 also highlighted that the Leader of the Opposition will be granted the status and provisions equivalent to a Federal Minister. Funding based on a transparent formula will be distributed to all members of the Dewan Rakyat allowing them to carry out responsibilities in their respective constituencies and to run their service centres. The Select Committee system with suitable provisions and appropriate support staff to enable them to function effectively will be established. For instance, a Dewan Rakyat Select Committee will be established to monitor every ministry, with the power to call Ministers and senior officials to testify.

Promise $16^{14}$ also includes key provisions on more transparent appointment procedures to key national institutions such as the Human Rights Commission of Malaysia (SUHAKAM), Election Commission (EC), the Malaysian Anti-Corruption Commission (MACC), and Judicial Appointments Commission (JAC) to be approved by a suitable Parliamentary Committee. Similar procedures are also envisaged for application to key bodies such as the Attorney General's Chambers, Bank Negara or National Bank, the Securities Commission (SC) and the National Audit Department. Additionally, Promise 16 stipulates the establishment of informal groups in Parliament allowing for more exchange of views between Members of Parliament and civil society. Increasing civil society engagement with the Members of

12 Malaysian Economic Association, MEA proposal: enhancing parliamentary committees in Malaysia. (2017).

13 Pakatan Harapan, supra note 2.

14 Ibid. 
Parliament is an excellent example of reform. This affords civil society groups the opportunity to voice their demands to Members of Parliaments through various channels including briefings and opening dialogue regarding any concerns.

As a way to ensure that people and stakeholders can engage in the policy making process, Promise 16 also emphasized the need to create a culture of producing Green Papers which would stimulate discussions as well as the development of White Papers to announce major government policies before a new Act is introduced in Parliament. This measure is deemed crucial as Members of Parliament during the last regime were often not provided with sufficient time to examine a new Act prior to its tabling. This left little room for scrutiny after an Act was approved and implemented as envisaged by the mechanism of the PLS.

During this period of democratic transition, it is widely agreed that more and better structured Parliamentary Committees are mechanisms for Members of Parliament to function as monitors, ensuring Ministries and Departments are operating in accordance with policies, rules and regulations approved by the Parliament. For instance, the Senate Reform Working Committee has called for the restoration of the Parliamentary Services Act 1963, which was repealed in 1992, in order to increase the autonomy of Parliament. The Act was fundamental, as it could ensure the separation of powers between Parliament and other jurisdictions. This can be viewed as a crucial step to finally do away with the "rubber stamp" label formerly attributed to Parliament. This also resulted in the perception of a lack of media coverage and communication with the public ${ }^{15}$, such a reform would open door for the PLS mechanism to be put in place.

The population's demands of the $\mathrm{PH}$ government are high. The calls for more information, enhanced democratic governance, transparency and accountability are visible. As mentioned earlier referring to the existing legislative governance structure in Malaysia, structured and systematic processes that can enable Parliamentary Committees to ensure a more comprehensive oversight over the Executive, as well as legislators to fully investigate work of the Executive and demand more accountability has been sorely missing. Democracy is based on the notion that all citizens have the right to participate in the management of political affairs and that every citizens input is of equal importance. This basic assumption places emphasis on public participation in maintaining a stable democracy. The level of public participation, however, is highly contested. There are two sides to this argument. Some voices maintain excessive public participation would stir and eventually paralyze the democratic system. On the other hand, others favour high levels of participation asserting more citizen involvement leads to greater representation. Irrespective of these disagreements over level of participation, there is widespread agreement amongst the scholars that, at the very least, a certain level of participation is necessary to maintain democratic systems. Due to these shortcomings, the on-going parliamentary reforms recognise the need for a mechanism to enable legislation to

15 Nurul Azwa Aris, "Senator wants Parliamentary Services Act restored for greater parliamentary autonomy”, (18 February 2019), online: Free Malaysia Today <https:/www.freemalaysiatoday .com/category/nation/2019/02/18/reforms-committee-chief-wants-parliamentary-services-act1963-restored/>. 
be debated thoroughly with the Members of Parliament granting them ample time to consider the various implications of the legislation. The proposal for greater public scrutiny of Bills which would lead to superior legislation and its implementation are not new, for example, it has been previously proposed by the Malaysian Economic Association. ${ }^{16}$

The 1Malaysia Development Berhad (1MDB) corruption scandal involving the former Prime Minister Dato' Seri Najib Razak triggered a discourse signalling an urgency to uphold and respect the independence of public institutions in carrying out their functions under the Federal Constitution and respective legislation. The separation of powers where the Legislative makes laws, the Executive carries out the laws and the Judiciary interprets and enforces the laws has become a mantra of the new government. The change in government is a beacon of hope for a more participatory approach by Parliament in overseeing and monitoring the ministries and departments through Parliamentary Select Committees.

As mentioned by a prominent constitutional law expert ${ }^{17}$ in Malaysia, the most significant function of Parliament is to enact, amend and repeal legislation or to delegate law-making authority to others in accordance with constitutional theory. No legislative proposal can, in theory, become law without going through the fires of scrutiny in both houses of Parliament. Unfortunately, Parliament's role in the legislative process in Malaysia is undermined by the Cabinet's pervasive dominance had led to a weakness pertaining to Parliamentary scrutiny of Bills. The author's advocacy experience suggests one of the key reasons is due to political loyalties, these prevent an objective consideration of Bills that are tabled, hence voting for or against is solely based on party lines. A recent study ${ }^{18}$ revealed $80 \%$ of Bills introduced by the Executive are passed without any substantive amendments with only $15 \%$ undergoing changes, whilst another $5 \%$ are either withdrawn or postponed by the Executive.

The legal mechanism for Parliament to appoint Special Select Committees is provided under Order 81 of the SOs. The Committee of Selection nominates Members of the special Select Committees, but they have the power to elect their own Chairman. Select Committees have the power to compel any person to appear and request documents and papers to be produced before them. Under the current parliamentary reforms, stakeholders and advocacy groups alike agree the need to review two draconian laws that contravene freedom of speech and expression of the Members of Parliament and citizens, namely the Penal Code and the Sedition Act 1948. The Penal Code sections 124(b)-124 (j) states "activity detrimental to parliamentary democracy"; the sections were deemed necessary to deal with violent offences such as assassination of Heads of State, coups, armed insurgencies and any form of breach of constitutional provisions. As for the Sedition Act 1948, its remit was to deal with "the threats against peace, public order and the security of Malaysia".

16 Malaysian Economic Association, supra note 12.

17 Shad Saleem Faruqi, "Restoring Parliament's eminence”, The Star (14 April 2016), online: <https://www.thestar.com.my/opinion/columnists/reflecting-on-the-law/2016/04/14/restoringparliaments-eminence-systems-in-which-people-participate-are-systems-they-are-likely-to-re>. 
Within both pieces of legislation, the definition of what constitutes "activity detrimental to parliamentary democracy" and "sedition" is vague and open to abuse. ${ }^{19}$ More recently, the Law Minister Datuk Liew Vui Keong announced that during a government Cabinet meeting the Sedition Act 1948 is to be abolished and they are currently considering factors to this effect. ${ }^{20}$

Since the change in government, among the parliamentary reforms that are newly introduced include the formation of the ten new bi-partisan parliamentary select committees, namely Special Select Committee for Consideration of Bills; Special Select Committee on Budget; Special Select Committee on Gender Equality and Family Development; Special Select Committee on Major Public Appointments; Special Select Committee on Defence and Home Affairs; Special Select Committee on State and Federal Relations, Special Select Committee on Election; Special Select Committee on Human Rights and Constitutional Affairs; Special Select Committee on International Relations and Trade; and Special Select Committee on Science, Innovation and Environment. A new Committee Parliamentary Caucus on Reforms has been formed and is headed by Dato' Seri Anwar Ibrahim, who is known as the Prime Minister-in waiting. The opposition has been allocated two places on each Committee. Additionally, a Special Cabinet Committee was also set up to review the implementation of the Malaysia Agreement 1963 (MA63) concerning the status of Sabah and Sarawak in East Malaysia. ${ }^{21}$

Moreover, a Select Committee for the $14^{\text {th }}$ Parliamentary Term, chaired by Dewan Rakyat Speaker Datuk Mohamad Ariff Md Yusof has been formed. The Committee has six members, namely Deputy Prime Minister Datuk Seri Dr Wan Azizah Wan Ismail, Home Minister Tan Sri Muhyiddin Yassin, Defence Minister Mohamad Sabu, International Trade and Industry Minister Ignatius Darell Leiking, Cheras Member of Parliament Tan Kok Wai and opposition leader Datuk Seri Dr Ahmad Zahid Hamidi. ${ }^{22}$ Prime Minister's Question Time will be one of three key changes to be introduced as a result of parliamentary reform. According to Deputy speaker Nga Kor Ming, the Prime Minister's Question Time will emulate the UK practice. There are plans for live telecast of the Question Times. There are plans for the Commission of Parliamentary Services Bill 2019 to be tabled in Parliament. The intent is to propose a separation between Parliament and the Executive through the Prime Minister's Department aligning it with the doctrine of the separation of powers. ${ }^{23}$

The setting up of the Parliamentarian Select Committees is not a new phenomenon in Malaysia. It has been in existence before the new government, the

19 Abdullah, supra note 5 .

20 "Sedition Act to be abolished, says Liew", The Star (10 May 2019), online: <https://www.thestar.com.my/news/nation/2019/05/10/sedition-act-to-be-abolished-says-liew/>.

21 Ibid.

22 Audrey Vijaindren, "Select committee, a positive progress in parliamentary reform, says C4", New Straits Times (8 August 2018), online: <https://www.nst.com.my/news/nation /2018/08/399440/select-committee-positive-progress-parliamentary-reform-says-c4>.

23 Ida Nadirah Ibrahim, "PM's Question Time part of parliament reform, says deputy speaker", The Malay Mail (11 May 2019), online: <https://www.malaymail.com/news/malaysia /2019/05/11/pms-question-time-part-of-parliament-reform-says-deputy-speaker/1751956>. 
difference being the new government has increased its engagement into this mechanism and has been putting an emphasis on the role of Members of Parliament including the role of the Parliament as a whole. For instance, a total of nine government agencies are now operating as independent entities since July 2018, reporting directly to Parliament. Among the agencies are the MACC, the EC, SUHAKAM, the Public Prosecutor's Office and the National Audit Department. All these are representative of the massive overhaul of the Prime Minister's Department.

In a research paper, entitled "Standing Committees for a New Malaysia", produced by a Member of Parliament Wong Chen, it has been recommended there should be nine new standing committees to supplement the five existing ones. Currently, there is a total of 25 Ministries and as a matter of principle, every Ministry ought to be accountable to one standing Committee. The aforementioned paper recommended there is a need to group Ministries by themes into standing Committees. In addition, the paper recommends Special Select Committees should be established on an ad-hoc basis with a budget of RM11.4mil to manage the operations of all committees. ${ }^{24}$

Discussions with various stakeholders and observers have led to a general acknowledgment regarding the decision-making weaknesses of the legislature. Prior to the 2018 general elections, PH had made promises of reforms including strengthening human rights and rule of law. But in a year, the new government has backtracked on introducing significant reforms including abolishing oppressive laws, ratifying the International Convention on the Elimination of Racial Discrimination (ICERD), ratifying the Rome Statute and abolishing the death penalty in totality. The situation is exacerbated by the Islamisation agenda pushed by right-wing politicians and NGOs for political advantage..$^{25}$

The Committee of Selection (excepting itself) whose members are appointed by the Dewan Rakyat, nominates the members of the Select Committees. The Speaker, except for the Public Accounts Committee, chairs each of the above Select Committees. The Dewan Rakyat appoints the Chairman and Deputy Chairman of the Public Accounts Committee. Order 81 of the SOs empowers the Dewan Rakyat to establish Select Committees apart from the five mentioned earlier. The purpose of the Special Select Committees is to inquire into and deliberate on such matters as determined by the Dewan Rakyat. In terms of composition of these Committees, SO 82(1) states that every Select Committee shall, so far as is practicable, reflect the balance of parties within the Dewan Rakyat. A Select Committee has the power to compel any person to appear before it and to ask for the production of documents and papers. Thus, parliamentary Select Committees are potentially powerful tools in a bid to increase government accountability. ${ }^{26}$

24 "Six new standing committees as first step towards New Malaysia”, The Star (5 December 2018), online: <https://www.thestar.com.my/news/nation/2018/12/05/six-new-standing-committees-asfirst-step-towards-new-malaysia>.

25 Hooi, supra note 4.

26 Dato' Mohd Hishamudin Yunus, "Parliamentary Select Committees" (2016) Lee Hishammuddin Allen \& Gledhill 48. 


\section{CHALLENGES AND RECOMMENDATIONS}

Although the mechanism are in place, thus far, there have been limited use of parliamentary Select Committees in Malaysian parliamentary practice. Prior to the change of government, there were only a handful of parliamentary Select Committees formed in Malaysia. These included the Parliamentary Select Committee on Integrity, on Electoral Reform, Unity and National Service and lastly on reviewing the Penal Code and Criminal Procedure Code in 2004. ${ }^{27}$ As highlighted in a working paper by a former Court of Appeal judge ${ }^{28}$,

"In fact, important Bills are rarely sent to a Special Select Committee for scrutiny; even so, very few Bills are amended at the committee stage due to political influence... Regrettably, the Houses are at their weakest in the matter of Parliamentary scrutiny of Bills. Parliament's role in the legislative process is undermined by the Cabinet's pervasive dominance. The Executive drafts the legislation and uses its Parliamentary majority to push a Bill through without much scrutiny.”

The government continues to face inherent challenges in the reforms they are seeking to implement. For instance, Dewan Negara has rejected the Country's controversial Anti-Fake News Act, which has been widely criticized as a tool to clamp down on the freedom of speech. Around 28 members voted against the repeal, compared to 21 who supported it whilst 3 chose to abstain. The Repeal Bill will return to Dewan Rakyat for re-tabling. ${ }^{29}$ After months, the government has announced the abolition of the death penalty for 32 offences under right acts of law. The government decided in March 2019 not to completely abolish the death penalty. Instead, they shall leave it to the courts to decide whether an offender will hang. ${ }^{30}$

In view of these challenges, the setting up of a Considerations of Bills Committee for instance can enable the participation of affected interests in the legislative process, allowing for a more thorough, constructive, systematic and non-partisan scrutiny of draft Bills. Since the change in government, the notion of public participation in matters related to government has increased. For instance, there has been increased scrutiny when it comes to government decisions. Whilst it has not all turned out well, examples include the government's withdrawal in signing Rome Statute, ICERD and abolishing the death penalty. To overcome this, a system of legislation committees could supply a much-needed corrective to this Executive dominance. ${ }^{31}$ Furthermore, Parliament should promote a culture of scrutiny, by learning from existing best practice across the world, such as step would serve to enhance the policy impact of

27 Ibid.

28 Ibid.

29 "Dewan Negara rejects Bill to repeal Anti-Fake News Act”, The Star (12 September 2018), online:<https://www.thestar.com.my/news/nation/2018/09/12/dewan-negara-rejects-bill-torepeal-anti-fake-news-act/>.

30 Channel News Asia, "Malaysia to keep death penalty, but no longer mandatory", online: $C N A$ <https://www.channelnewsasia.com/news/asia/malaysia-death-penalty-not-completely-abolished$11340612>$.

31 Faruqi, supra note 17. 
Parliament. References are often made to the list of Select Committees in the Parliaments of the countries that have the Westminster parliamentarian system that is practiced in Malaysia these include UK, Australia, Canada and New Zealand.

Many share the sentiment that this period of democratic transition is crucial for Malaysia, there is a need to move away from the brand of democracy that revolves around political parties or coalitions in the context of Malaysia as is often demonstrated by debates in the Dewan Rakyat. Partisan politics overshadow the main issue regarding a Bill, as was the case with the Anti-Fake News Bill. Often draft Bill are made available to Members of Parliament at the last minute, to the public following the first reading, this leaves limited time for Members of Parliament to engage in rigorous debate. For instance, the controversial National Security Council Bill 2015 was rushed through Parliament and passed late at night despite strong resistance from the population. ${ }^{32}$ The lack of Special Select Committee on Bills at the time worsened the situation. At present, considering the imperative need for effective check and balance mechanisms to safeguard public interests against abuses of power, Parliament needs to adopt a dynamic approach in overseeing the functions of government, particularly the running and performance of the ministries and departments.

In examining the scenario of the Malaysian legislature, the parliamentary reforms at the national level have started progressively but at the State level, many have pointed to the Selangor State Assembly model, where a parliamentary committee system is established. The State of Selangor witnessed the change of State government to the-then opposition in 2008 during Malaysia's 12 $12^{\text {th }}$ general election. At that time, the Selangor Legislative Assembly had undergone a series of legislative reforms. For instance, check and balance mechanisms have been put in place in Selangor to strengthen the legislature.

Since 2008, the Selangor Legislative Assembly has formed six Select Committees and four special Select Committees. These Committees meet when the State assembly is not in session and help to provide legislative scrutiny on executive administration. The Select Committees are as follows: the Public Accounts Committee, Select Committee of District and Land Office, Select Committee of Local Authority, Select Committee of Agency, Statutory Body and Subsidiary Company, Standing Orders Committee, and Rights and Privileges Committee. On the other hand, the special select committees, formed through a motion in the legislative assembly, focus on specific issues, namely Selangor Competency, Accountability and Transparency Committee (Selcat), Special Select Committee on Poverty Eradication, Special Select Committee on Management of the Assembly, Special Select Committee on Water Resources Management of the State of Selangor (JPK-SAS). Overall, the Committees are formed with the aim to provide systematic legislative checks and balances to the Executive branch of power.

Aside from Select Committees and the necessary standing order amendments to strengthen the legislature, the author has discovered there is consensus that it is equally important to institutionalize government transparency via law reform.

32 Yunus, supra note 26. 
However, the author affirms there has been limited discussion around the importance of PLS. The current democratic transition Malaysia is undergoing has resulted in various reforms taking place therefore PLS may not be a priority for time being.

When asked to describe the issues in Malaysia, it is commonly agreed that the acceptance of a minimal role in basic policy decisions is accompanied by the perception that the important decisions are solely dependent on the Cabinet and the government as a whole. This is due to a deficit in frameworks for policymaking influence beyond decisions in the Cabinet that have led to the perception that Dewan Rakyat is simply a platform to debate decisions that have already been made earlier. Efforts have been made to be more inclusive by incorporating opposition parliamentarians in several Parliamentary Committees, the notion of winner-takes-all practice in the past Malaysian political competition needs re-examining. Negative values have been inculcated for too long in society, it is time for the new government to shift this approach by investing time to understand the masses and promote a positive political culture. One cannot necessarily legislate political culture however, the new government ought to find ways to reduce fear that each group has of the other. ${ }^{33}$ The fragility of democratic transition in Malaysia with its strong foundation of ethnic politics is a ticking time bomb. Empowered Select Committees could enhance the effectiveness of Parliament and the State assemblies in providing checks and balances on the power of the Executive.

Out of the hundreds of proposals that the IRC have received, only a few relate to improving the institutional efficacy of our elected legislature. The Malaysian system of parliamentary democracy states the legislature is to perform the enacting, amendment and repealing of laws to ensure accountability, answerability and responsibility of the political executive to Parliament. Yet, Parliament has not managed to fulfil these functions satisfactorily. ${ }^{34}$ Shad Faruqi Saleem ${ }^{35}$, a prominent constitutional expert, puts forward a number of debilitating factors and recommendations to enhance parliamentary democracy. It is proposed that in order to strengthen Parliament's legislative role, for the pre-legislative scrutiny, the government must issue policy papers on proposed Bills to enable citizens to provide feedback. Draft copies of the Bills must be supplied to all Members of Parliament at least two weeks before the first reading. It is also been recommended the Committees should invite experts to give evidence which may involve participation by NGOs to reflect the democratic impulses of society.

Saleem $^{36}$ goes on to state the Select Committee on Subsidiary Legislation must be appointed to advise Parliament on whether to accept or annul a subsidiary law. The two Houses referring to Dewan Rakyat and Dewan Negara should set up a Joint Select Committee on Law Reform. An independent Law Reform Commission

33 Hooi, supra note 4.

34 Shad Saleem Faruqi, "Proposals for parliamentary reforms", The Star (21 June 2018), online: <https://www.thestar.com.my/opinion/columnists/reflecting-on-the-law/2018/06/21/proposalsfor-parliamentary-reforms-post-ge14-the-institutional-efficacy-of-our-elected-legislature>.

35 Ibid.

36 Ibid. 
should report to this Committee to ensure that the elected representatives have a say in keeping the law responsive to the necessities of the time. In addition, in order to overcome the lack of literacy on Federal Constitution and the laws of Parliament, an Institute of Parliamentary Affairs should train Members of Parliaments on the Constitution and laws of Parliament. It is also suggested that the special Committees should ensure that Bills are not withdrawn after presenting to Parliament. If stakeholders disagree with aspects of legislation, these can be highlighted in the Committee stages instead of in the debates in the Dewan Rakyat. Incorporating public scrutiny would make better laws and be sensitive to society's needs. This can further enhanced by allowing the media to sit in on the hearings, providing them with a fuller picture on the intricacies of issues. ${ }^{37}$

In order to advance greater participation from Members of Parliament, they should be permitted to initiate private Member's Bills, Motions and propose procedures to expedite and enhance government business. This would encourage leadership and initiatives from Members of Parliaments as well as act as a step to promote PLS and building capacity for stronger legislation, motions and processes. Another shortcoming is the lack of research support for Members of Parliament. Research is crucial to initiate policies and legislation which when backed by evidencebased and substantive arguments, enable quality discussions and debates in Parliament. Additional identified challenges include resources and the establishment and greater use of Parliamentary Select Committees. ${ }^{38}$ Parliament's Select Committees must be afforded power and autonomy to hold inquiries on matters of public interest with meaningful participation if a PLS mechanism is put in place. For instance, the Parliamentary Select Committees should be empowered to initiate its own investigations and act as an oversight body that tracks the government's progress, with each panel having its own areas of expertise to speed up inquiries and make recommendations independently. Subsequently for a follow-up mechanism as inspired from the PLS mechanism, the findings should be debated in Parliament and made public for further action.

This paper also discovered the intense parliamentary reforms have raised concerns amongst Members of Parliament. As told by the Dewan Rakyat Speaker Mohamad Ariff Md Yusof in an interview with a newspaper ${ }^{39}$, he plans to slow down the pace of parliamentary reform to enable Members of Parliament to better understand and adjust to the changes. He responded due to budding concern from certain quarters "within the executive" and the broader public that Parliament was wielding too much power. Nonetheless, the Speaker is planning to set up 5-9 more Parliamentary Select Committees focusing on the environment and climate change; international trade and foreign affairs; as well as human rights and constitutional affairs.

37 Abdullah, supra note 5.

38 Lee, supra note 3.

39 Malaysiakini, "Parliament 'too powerful'? Speaker to slow down reforms to help MPs adapt", Malaysiakini (26 April 2019), online: <https://www.malaysiakini.com/news/473799>. 


\section{CONCLUSION}

The hard truth is the process of transition to democracy is often difficult and painful. In the case of Malaysia, much success will depend on the quality of leadership at all levels and the ability to sustain a vibrant civil society for the check and balance mechanism..$^{40}$ The challenges are also partly due to the institutional constraints built into Malaysia's political system that hinder the process of PLS. The government will need to capitalize on the transition to establish and introduce the PLS mechanism whilst parliamentary reforms are being undertaken to foster enduring democracy. The current government under Mahathir's administration has emphasized the philosophy of good governance, consisting of transparency, accountability and openness. What is significant is that discussions focusing on bureaucratic reform and a need to overhaul the governance system in Malaysia have been bought to the fore.

Whilst a space for discussion has arguably opened, the old discourse centred on partisan politics in Malaysia has not been entirely dismissed. There is a need for these blunt conversations to continue particularly how to preserve political openness where it exists in order to avoid missed opportunities, and at the same time, how to restore space in the cases where it has been disrupted. Institutional, legislative and judicial reform are key items on the new government agenda. In terms of legislative reform, it will likely encounter delays in the coming years. Thus, whilst the legislative debate is ongoing, the enhancement of check and balance mechanisms is predicted to take somewhat longer. By having a series of reforms in the pipeline, it is hoped Parliament will eventually be an effective check-and-balance against the executive and judicial branches and will result in Members of Parliaments having a greater say in formulating laws and policies and increasing accountability to the population.

\section{BIBLIOGRAPHY}

Abdullah, Maria Chin. "Time for Parliamentary Reform”, (14 March 2019), online: The Sun Daily <https:/www.thesundaily.my/opinion/time-for-parliamentaryreform-GM680923>.

Ahmad, Zakaria Haji. "Malaysia: Quasi Democracy in a Divided Society" in Larry Jay Diamond, Juan José Linz \& Martin Lipset, eds, Democracy in Developing Countries: Asia (L. Rienner, 1989).

Aris, Nurul Azwa. "Senator wants Parliamentary Services Act restored for greater parliamentary autonomy”, (18 February 2019), online: Free Malaysia Today <https:/www.freemalaysiatoday.com/category/nation/2019/02/18/reformscommittee-chief-wants-parliamentary-services-act-1963-restored/>.

Case, William. "Malaysia: the semi-democratic paradigm" (1993) 17:1 Asian Studies Review 75-82.

40 Hooi, supra note 4. 
Channel News Asia. "Malaysia to keep death penalty, but no longer mandatory", online: CNA <https://www.channelnewsasia.com/news/asia/malaysia-deathpenalty-not-completely-abolished-11340612>.

Faruqi, Shad Saleem. "Proposals for parliamentary reforms", The Star (21 June 2018), online: <https://www.thestar.com.my/opinion/columnists/reflecting-onthe-law/2018/06/21/proposals-for-parliamentary-reforms-post-ge14-theinstitutional-efficacy-of-our-elected-legislature>.

—_. "Restoring Parliament's eminence”, The Star (14 April 2016), online: <https://www.thestar.com.my/opinion/columnists/reflecting-on-the-law/2016/ 04/14/restoring-parliaments-eminence-systems-in-which-people-participate-aresystems-they-are-likely-to-re>.

Hooi, Khoo Ying. "A year after Malaysia changed government: A messy democracy but necessary”, The Malay Mail (8 May 2019), online: <https:/www.malaymail. com/news/what-you-think/2019/05/08/a-year-after-malaysia-changedgovernment-a-messy-democracy-but-necessary-kh/1751027>.

Ibrahim, Ida Nadirah. "PM's Question Time part of parliament reform, says deputy speaker”, The Malay Mail (11 May 2019), online: <https://www.malaymail.com/ news/malaysia/2019/05/11/pms-question-time-part-of-parliament-reform-saysdeputy-speaker/1751956>.

Lee, Cassey. "Making Sense of Malaysia’s Institutional Reforms" (2018) 79 ISEAS 11.

Malaysiakini. "Parliament 'too powerful'? Speaker to slow down reforms to help MPs adapt”, Malaysiakini (26 April 2019), online: <https:/www.malaysiakini.com/ news/473799>.

Malaysian Economic Association. MEA proposal: enhancing parliamentary committees in Malaysia. (2017).

Mauzy Diane K. “The Challenge to Democracy Singapore's and Malaysia’s Resilient Hybrid Regimes” (2006) 2:2 Taiwan Journal of Democracy 47-68.

Means, Gordon Paul. "Soft Authoritarianism in Malaysia and Singapore” (1996) 7:4 Journal of Democracy 103-117.

Pakatan Harapan. "Buku Harapan: Rebuilding our nation, fulfilling our hopes", (2018), online: <https://kempen.s3.amazonaws.com/manifesto/Manifesto_text/ Manifesto_PH_EN.pdf>.

Teik, Khoo Boo. "Review of Goverment and Society in Malaysia” (1999) 72:2 (277) Journal of the Malaysian Branch of the Royal Asiatic Society 194-196.

The Economist Intelligence Unit. Democracy Index 2017: Free speech under attack, by The Economist Intelligence Unit (2017).

The Star. "Dewan Negara rejects Bill to repeal Anti-Fake News Act”, The Star (12 September 2018), online: <https://www.thestar.com.my/news/nation/2018/ 09/12/dewan-negara-rejects-bill-to-repeal-anti-fake-news-act/>. 
—. "Sedition Act to be abolished, says Liew", The Star (10 May 2019), online: $<$ https://www.thestar.com.my/news/nation/2019/05/10/sedition-act-to-beabolished-says-liew/>.

—. "Six new standing committees as first step towards New Malaysia”, The Star (5 December 2018), online: <https://www.thestar.com.my/news/nation/2018/12/ 05/six-new-standing-committees-as-first-step-towards-new-malaysia>.

Vijaindren, Audrey. "Select committee, a positive progress in parliamentary reform, says C4”, New Straits Times (8 August 2018), online: <https://www.nst.com.my /news/nation/2018/08/399440/select-committee-positive-progressparliamentary-reform-says-c4>.

Yunus, Dato' Mohd Hishamudin. "Parliamentary Select Committees" (2016) Lee Hishammuddin Allen \& Gledhill 48.

Khoo Ying Hooi is Senior Lecturer at the Department of International and Strategic Studies, University of Malaya. She completed her PhD in Politics and Government with her thesis on social movements and democratization. She is the Editor-in-Chief of Malaysian Journal of International Relations and sits in the editorial board of Suvannabhumi: Multi-disciplinary Journal of Southeast Asian Studies. 